\title{
Customer Relationship Management (CRM) Analysis and Design to Provide Customer Service in The Culinary Field (Case Study Restaurant XYZ)
}

\author{
${ }^{1}$ LORIO PURNOMO, ${ }^{2}$ SFENRIANTO \\ ${ }^{12}$ Information Systems Management Department, BINUS Graduate Program - Master of Information Systems \\ Management, Bina Nusantara University, Jakarta, 11480, Indonesia \\ E-mail: ${ }^{1}$ lorio.purnomo@binus.ac.id, ${ }^{2}$ Sfenrianto@ binus.edu
}

\begin{abstract}
There has been a lot of discussion regarding Customer Relationship Management (CRM) in recent years, where the CRM function to provide customer service in the culinary field has been widely applied by culinary business entrepreneurs. Restaurant XYZ, which started the culinary business in 2018, will design a CRM system to improve service to its customers, this is because it has not been optimal in the process of providing services to its customers. Before doing the design, an analysis phase is needed which is carried out using the Fishbone Method, this method is expected to help in analyzing the constraints and needs of the Restaurant XYZ in the best CRM design. The design using the Diagram Unified Modeling Language (UML) and User Centered Design (UCD) approach, is expected to create a CRM system as expected by the owner of Restaurant XYZ. The CRM that has been planned is expected to help the owner in providing services to Restaurant XYZ customers.
\end{abstract}

Keywords: Customer Relationship Management (CRM), Fishbone Diagram, User Centered Design (UCD).

\section{Introduction}

The digital world is inevitable in this Millennial era, almost everyone in this world carries out their daily activities cannot be separated from digital activities. From a business point of view, it has now been made easier by the existence of this digital world. Researchers try to reveal in terms of the culinary business, where with the convenience of the digital world, the culinary business has become a business activity that opens opportunities and hopes to pursue better income from the culinary business. This is also strengthened from the Statistical Data and CREATIVE ECONOMIC Survey Results of the Cooperation between the Creative Economy Agency and the Central Statistics Agency on March 8, 2017, as shown in Figure 1 below.[1]

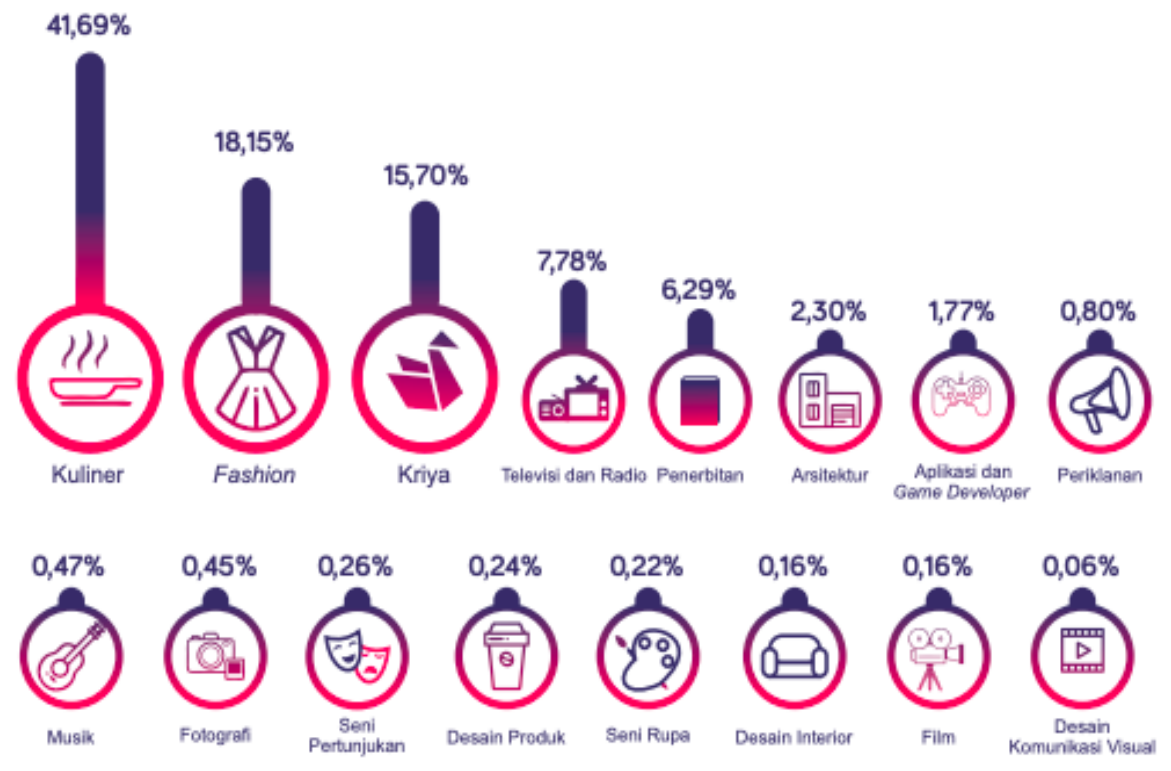

Figure 1.Culinary business increase data in 2017[1] 
The data above, it shows that the culinary business has grown so rapidly in 2017, even until 2020, the culinary business is increasingly mushrooming, both for MSMEs (Micro, Small and Medium Enterprises), to Restaurant entrepreneurs who have very large capital.

Now the culinary business relationship with the digital world is getting closer and easier. It's so easy to reach the desired information, making all culinary lovers can easily and quickly find culinary places of interest. Digital developments also change the habits of consumers or customers, who previously were more likely to come and eat at restaurants that they like, but the digital worldforms new habits, so that the development of population spending changes, leading to food and drink shopping that is increasing. This information is strengthened from Figure 2 below.[2]

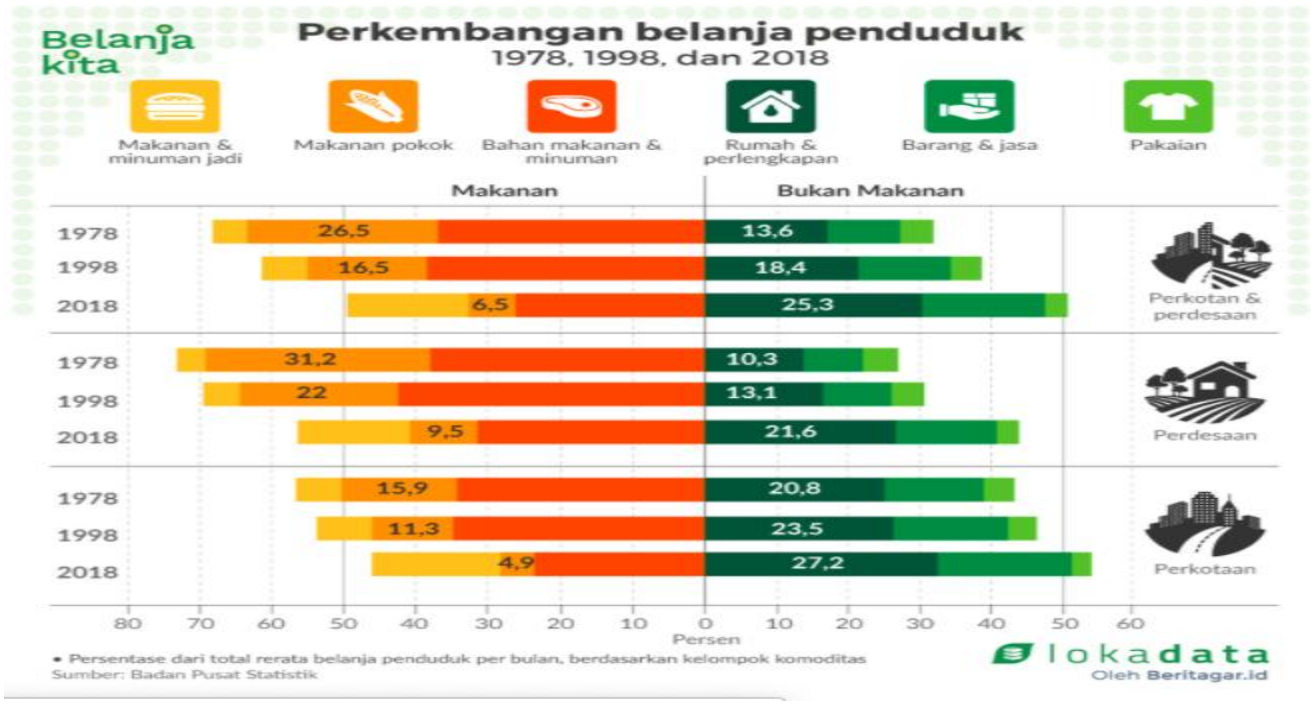

Figure 2. Product shopping development data [2]

In the data processed by Lokadata Beritagar.id, the tendency of consumers to buy processed food has indeed begun to increase in the last 20 years. Changes in the activities of everyone, reducing the time for daily cooking. In the end, many people are turning to instant food and fast food. The change in the cost of food purchases is 1.3 times greater than that of staple food. This change in public consumption patterns is an opportunity for several application-based food delivery service companies or in other words starting in the digital world such as GoFood, a food delivery service part of the Go-Jek ecosystem that claims to have increased order number messages throughout 2018.

Seeing the above information about the relationship between the culinary business and changes in consumption that have led to digital, it has made many culinary entrepreneurs try to implement their business more towards digital and start implementing Customer Relationship Management (CRM). Seeing this condition intrigued the researcher to conduct research from a case study at Restaurant XYZ.

Restaurant XYZ business is engaged in the culinary field since 2018, at the beginning of his business until when the author conducted this research, Restaurant XYZ has not used an integrated system, or it can be said that it has not been towards optimal digital. Even though they already have a website that can be accessed by many people. Then look at the development of the culinary business that is increasingly booming today, accompanied by changes in consumption patterns, and the development of the culinary business using online technology. So, the owner who is also the director of Restaurant XYZ wants to create an integrated CRM system, in order to develop his business and also provide convenience in serving his services to all Restaurant XYZ customers. With the current situation where Restaurant XYZ has not implemented Customer Relationship Management (CRM), the author tries to provide analysis first to provide CRM design to the Restaurant XYZ owner. Where the business development is also increasing, with the number of customers increasing.

Designing Customer Relationship Management (CRM) is a customer service approach that focuses on building long-term and continuous relationships with customers. CRM has the potential to help companies achieve their goals, namely increasing the lifetime value of each relationship to increase revenue and profits.[3]

User Centered Design (UCD) is a philosophy regarding the design of a system that places the user at the center of a system development process. The difficulty of end users so far in reading and translating documents in each development can be helped by using the UCD method. Techniques, methods, tools, procedures and processes 
that help design interactive systems are built on the basis of user experience. UCD is translating human participation and experience into designs.[5]

Based on this background description, the following problems can be formulated:

(1) How is the Restaurant XYZ Customer Service Analysis using the Fishbone Method?

(2) What are the stages of CRM design using the UCD method in Restaurant XYZ?

The purpose of this paper is as follows:

The author analyzes the process between Restaurant $\mathrm{XYZ}$ and customers, from the results of this analysis whether the process is running as expected by the owner of the Restaurant XYZ. To facilitate the analysis, the authors conducted the Fishbone Method, from the current process at Restaurant XYZ. Where with this Fishbone Method to help identify the root cause of a problem faced by Restaurant XYZ and help find ideas for a solution to a problem, the solution can be a reference or what steps should be taken by Restaurant XYZ.

Designing a CRM using the User Centered Design (UCD) method, the UCD Method can translate human participation and experience into a design. This is in line with the needs and desires of Restaurant XYZ owner.

\section{Literature Review}

\subsection{Customer Relationship Management}

In concept, CRM is a business model that aims to identify, anticipate, understand the needs of customers, both current customers and those who are considered potential customers by gathering information about customers, sales, marketing effectiveness, and market trends.

Customer Relationship Management is a strategic process to select customers who are useful to serve and form interactions between companies and customers to get various kinds of benefits. The main purpose of this process is to optimize the current and future value of the customer for the benefit of the organization [5].

The principles of CRM are in business organizations in increasing customer loyalty and satisfaction without adding to the burden of cost and time. With the application of CRM in an organization, it is expected to be a relevant solution for investing in IT in the digital era. If an organization cannot know who customer is, what is needed, it is certain that the organization cannot keep that customer into a loyal customer, and organizational automation is difficult to win the business competition.

CRM can be applied with a technology that is integrated in all functions in an organization, to achieve its goals, the CRM strategy is not only about improving customer service, but how the organization creates sustainable and reliable interactions and access can be easily used by both parties, customers and organizations or companies.

\subsubsection{Purpose of CRM}

CRM can be applied with a technology that is integrated in all functions in an organization, to achieve its goals, the CRM strategy is not only about improving customer service, but how the organization creates sustainable and reliable interactions and access can be easily used by both parties, customers and organizations or companies.

The purpose of CRM is to manage and manage customers so that there is a good relationship between the company and customers.[6]

Optimizing existing customers to further increase company revenue. Prepare complete information about customers to maximize customer relations with the company through up-selling and cross-selling so that at the same time it can increase profits by identifying, attracting, and retaining better customers.

Using integrated information to produce the most satisfying service. By using information needed by customers, we can save customer time and avoid customers from various kinds of complaints.

\subsubsection{CRM Cycle}

The CRM cycle which consists of the Acquire- Retain - Expansion process, each phase in the cycle can be explained as follows: [6] 
Acquire, the process of acquiring a new relationship is to acquire new customers which can be realized in various strategies. The key words associated with this phase are differentiation, innovation, and convenience (convenience).

Retain, retaining customer relationship is the phase where the organization performs a strategy to retain customers by improving service. Customer retention is an important strategy for companies because more and more choices for customers are being created by many service provider organizations (competitors). The keywords associated with this phase are adaptability, listening, and responsiveness.

Expansion is a period to foster good existing relationships with customers, by always listening to the wishes of customers and serving them well, creating loyal customers to the organization's products / services. Some of the keywords associated with this phase are loyalty, reduce costs, and customer service.

\subsubsection{CRM and Loyalty}

Customer Relationship Management is used by companies that want to build good relationships with customers and need to know about their customers. Such as knowing about their demands, needs and expectations which can be adjusted from the product / service being offered. By managing knowledge about customers, it is possible to build and maintain satisfying and mutually beneficial relationships. Through high customer loyalty, companies can gain a competitive advantage. CRM helps improve the interface to the customer and aims to increase customer satisfaction. CRM can also be defined as a customer-oriented and IT-based management concept with the aim of building long-term and profitable customer relationships for the company. To assess future customer behavior and offer the best service, it is necessary to exploit, evaluate and regularly update the company's knowledge of customers. If a company aims to increase customer loyalty and thus its success, the company needs to fulfill various subtasks. [7,8] CRM can be divided into 3 types with different tasks.

The purpose of Collaborative CRM is to optimize customer contact. The duration and frequency of direct interactions between customers and companies must be minimized for the sake of automation, or what can be called passive interactions. Classic means of communication such as telephone, fax and postal services must be complemented by modern electronic technology such as e-mail and SMS services to establish a "Customer Interaction Center". By involving customers directly, the information obtained can be adjusted.

In contrast, operational CRM provides members of marketing, sales and customer service with relevant customer and market information. They are employees who are responsible for customer service and so have permanent access to the data collected. Through each contact, they will be better able to complete the customer profile and thus be able to take a comprehensive view of the customer. Information regarding delivery times, inventory, etc. helps to make a reliable statement on the customer. In short: operational CRM aims at customer service optimization.

While Collaborative CRM and CRM operations support business processes with customers, Analytical CRM focuses on collecting, processing, and analyzing customer data by using Business Intelligence Applications (Data Warehouse, Data Mining, etc.). Its purpose is to identify potential sales as well as costs in marketing, sales, and customer service. In short, the data warehouse is a gold mine of information. By combining employees, and designing company processes accordingly, different types of CRM can help increase company productivity, increase sales, and increase quality levels. It can be concluded that CRM is used to help improve the interface to customers and aims to increase customer satisfaction. CRM can also be defined as a customeroriented and IT-based management concept with the aim of building long-term customer relationships and benefiting the company and creating customer loyalty.

\subsection{Customers}

Customers are individuals or groups who buy a product or service based on their decisions based on considerations of the benefits and prices of the product or service [9]. Customer loyalty is measured by two items, assessing repurchase intention and others willingness to recommend to others [10].

The advantages of customer loyalty are as:

(1) Loyal customer service costs less than new customers

(2) They will pay a higher fee for a set of products, and

(3) For companies, loyal customers will act as word-of-mouth marketing agents.

There are three characteristics of customers who are loyal to a company [11]:

First: say positive things about the company; Second: recommending companies or services to others; Third: intention to buy or use the company's services. 


\subsubsection{Customer Loyalty is Important}

There are six reasons why an institution needs to get customer loyalty.[12] First: existing customers are more prospective, meaning that loyal customers will provide great benefits to the institution. Second: the cost of acquiring new customers is much greater than maintaining and retaining existing customers. Third: customers who already trust the institution in one business will also trust in other matters. Fourth: the institution's operating costs will be efficient if it has many loyal customers. Fifth: institutions can reduce psychological and social costs because old customers have had many positive experiences with the institution. Sixth: loyal customers will always defend the institution and even try to attract and advise others to become customers.

\subsubsection{Loyalty}

Loyalty can be defined as loyalty, which is one's loyalty to an object. [13] Loyalty as a condition in which customers have a positive attitude towards a brand, have a commitment to the brand, and intend to continue their purchases in the future. Loyalty shows the tendency of customers to use a certain brand with a high level of consistency [14].

This means that loyalty will continue to be related to the preferences of the customer and from each actual purchase. The definition of loyalty from the experts mentioned above is based on two approaches, namely attitudes and behavior. In the behavioral approach, one must fully understand the difference between loyalty and repurchasing behavior. Repurchasing behavior can be defined as the behavior of a customer who only buys a certain product repeatedly, without including feelings and ownership aspects in it. Conversely, loyalty contains aspects of customer preference for a product.

This means that the attitude aspect is involved. Loyalty develops following three stages, namely cognitive, affective, and conative. Usually, customers become loyal first to the cognitive aspect, then the affective aspect, and finally the conative aspect.

These three aspects are usually compatible, although not all cases experience the same.

First stage: Cognitive Loyalty Customers who have this first stage of loyalty use information on the superiority of a product over other products. Cognitive loyalty is based more on functional characteristics, especially cost, benefit, and quality. If these three factors are not good, customers will easily move to other products. Customers who only activate their cognitive stage can be hypothesized as the customers most vulnerable to switching due to marketing stimuli [14].

The second stage: Affective Loyalty Attitude is a function of cognition in the initial period of purchase (the period before consumption) and is a function of the previous attitude plus satisfaction in the next period (the period after consumption). The emergence of this affective loyalty is driven by the satisfaction factor which gives rise to liking and makes objects as preferences. Customer satisfaction has a high correlation with repurchase intentions in the future. In affective loyalty, customer vulnerability is more focused on three factors, namely dissatisfaction with existing brands, persuasion from marketers and customers of other brands, and efforts to try other products [16].

The third stage: Conative Loyalty shows an intention or commitment to do something. Intention is a function of prior intention (in the period before consumption) and attitude at the time after consumption. So, conative loyalty is a loyalty that includes a deep commitment to make a purchase. The results of research [15] which used a sequence model of attitudes: belief - attitude - intention showed commitment to doing (intention) causing voter preferences to remain stable for 3 years. This type of commitment goes beyond affective. Affective only shows a motivational tendency, while commitment to do shows a desire to carry out the action. The desire to repurchase or be loyal is only anticipated but not yet fulfilled. To complete the loyalty sequence, one more stage is added to the cognitive-affective-conative model, namely action loyalty.

Fourth stage; Loyalty Actions Conative aspects or the intention to do develop into behavior and actions. Intention followed by motivation, is a condition that leads to readiness to act and a desire to overcome obstacles in carrying out these actions. So that loyalty can become a reality through several stages, namely first as cognitive loyalty, then affective loyalty, and conative loyalty, and finally as action loyalty. A fully integrated customer at the action loyalty stage can be hypothesized as a customer with a low level of vulnerability to switch to another product. In other words, the loyalty of this action is little or no opportunity for customers to switch to other products. On loyalty and action, customer vulnerability is more focused on factors of persuasion and the desire to try other products. 


\subsection{CRM Analysis and Design Stages}

Several methods approach to do Analysis and Design for CRM in Restaurant XYZ. Researchers try to describe and use the following approaches.

\subsubsection{Fishbone Diagram}

Fishbone diagram or also known as Ishikawa diagram was introduced by Kaoru Ishikawa in 1960 [16], who at that time pioneered the quality management process at the Kawasaki Japan shipyard and became one of the founders of modern management. The fishbone diagram is shown below.

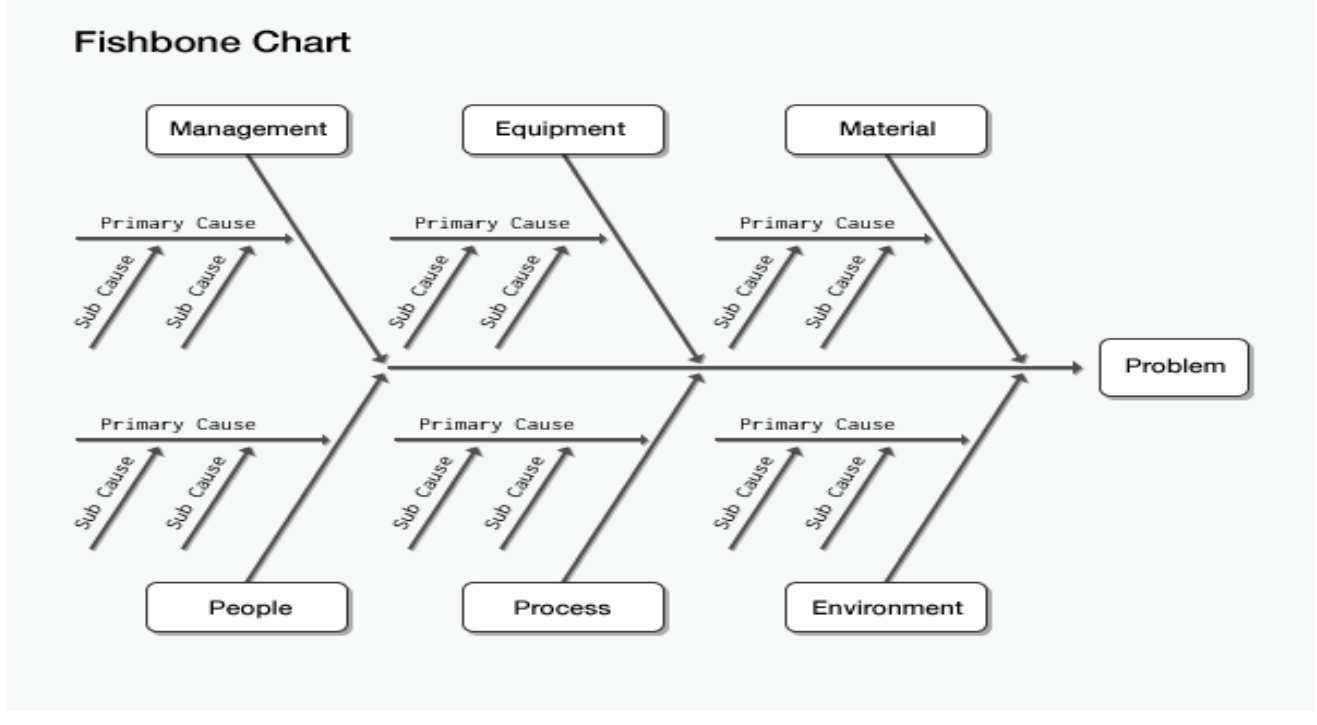

Figure 3.Fishbone Diagram

- Cause is usually grouped into several main categories to identify sources - varied sources. The categories usually include: 1 . People; Anyone involved in the process.

- Methods / Management; How is the process carried out and the specific requirements for doing it, for example, procedures, policies, rules, and others.

- Machines / Equipment; Process support equipment.

- Materials; Raw materials, spare parts in making products.

- Measurement / Process; Data used to measure a process.

- Environment; Conditions, work culture and climate.

By listing the causes as in the category of causes above, a solution to the effects / problems of a process can be found. This certainly makes it easier for analysts to determine which are the main and secondary factors. Fishbone diagram is a method for analyzing the causes of a problem or condition.

This diagram can also be called a cause-effect diagram or cause effect diagram. The function of this diagram is to:

(1) Identify the causes of a problem.

(2) Get ideas that can provide solutions for solving a problem.

(3) Assist in finding and further investigation of facts.

\subsubsection{Unified Modeling Language}

The Unified Modeling Language is a standard set of information model constructs and has a notation defined by the Object Management Group [17]. The following is part of the UML, including:

\section{Activity Diagram:}

In information system development, business process modeling is indispensable in describing ongoing business processes or those that will be developed. One of the models commonly used is an activity diagram. 
UML activity diagrams resemble horizontal flowcharts that show actions and events as they occur [18]. Activity diagrams are used for all types of modeling activities that are described in the context of business process modeling [19]. This means describing the process or activity carried out and how objects or data are moved. Activity diagram is a UML diagram that describes the activity of the user (or system), the person or component that completes each activity, and a sequence of all activities carried out. Activity diagram elements can be seen in the following figure [18]:

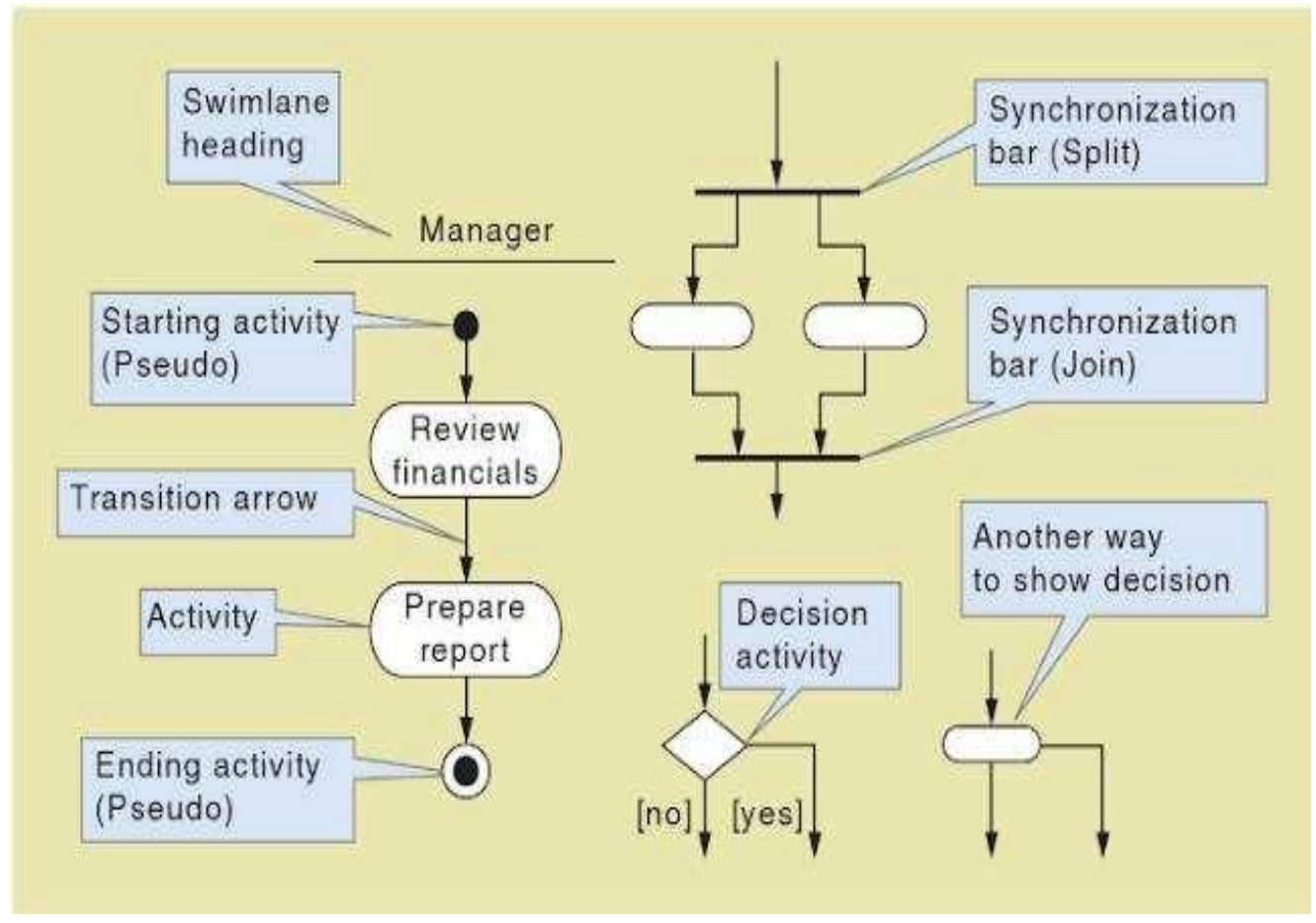

Figure 4. Activity Diagram Element [18]

Description of the Activity Element Diagram above:

(1) Swimlane heading is a column activity diagram that contains all activities for a single agent or organizational unit.

(2) Synchronization bar is a component activity diagram that separates control lines into several concurrent lines (split) or combines concurrent paths (join).

(3) Starting activity is a component of a diagram activity that gives an initial sign of starting an activity diagram.

(4) The transition arrow is a component of the activity diagram which indicates the workflow that occurs in the activity diagram.

(5) Activity is a component of activity diagram which contains activities that take place in an activity diagram.

(6) Ending activity is a component of a diagram activity which marks the end of an activity diagram.

Decision activity is a component of a diagram activity that is used when an activity has a choice in an activity diagram.

\subsubsection{User Centered Design}

User Centered Design (UCD) is a method in designing a design that focuses on user needs. In relation to Information Systems, User Centered Design is part of the SDLC (System Development Life Cycle), so that application designs developed through UCD will be optimized and focus on end-user needs so that it is expected that applications will follow user needs and users do not need to change behavior to use the application. To run UCD properly requires experimentation, iteration and experience when it fails. Therefore, there are principles in UCD that can be used as a guide in running UCD, including: 
Clearly understand the user, along with the work done and the environment in which the user is located. The design is based on the evaluation carried out in each iteration. Prioritizing usage experience. Involving the client in making and designing designs.

The process in UCD requires the designer to combine investigative elements (for example: surveys and interviews) as well as generative elements (for example: brainstorming) to provide and define the needs of the user. In general, the UCD process is in the form of iteration, which is repetition and evaluation that is carried out in each process before proceeding to the next process. In general, there are 4 stages in the UCD process, [20,21] namely:

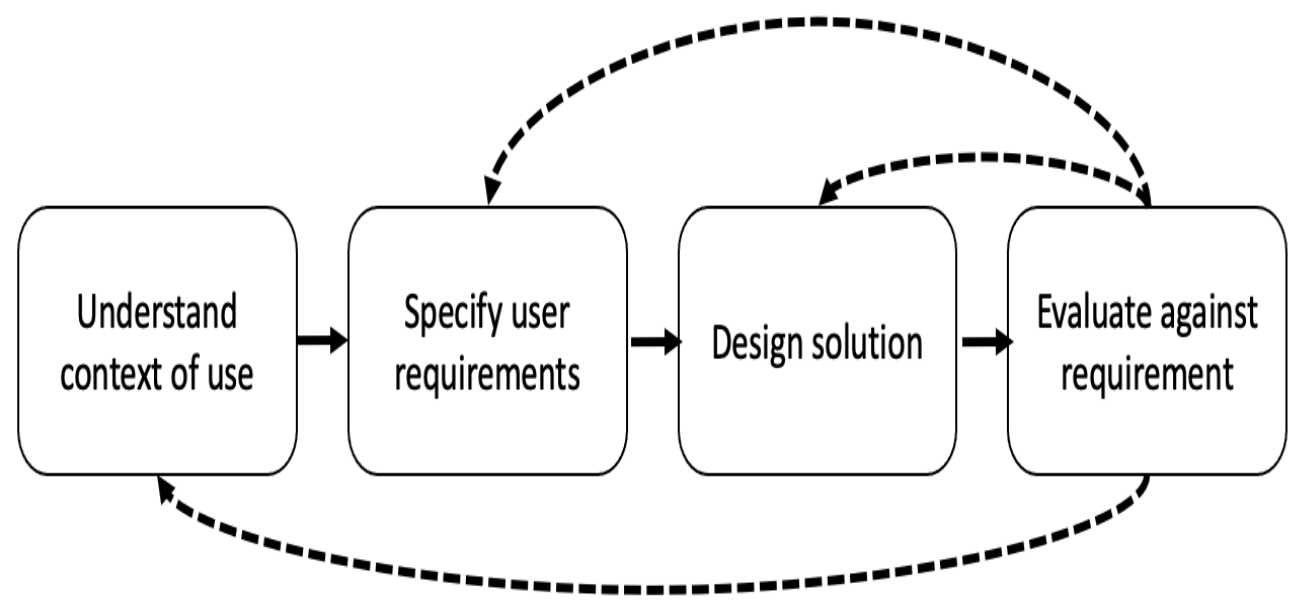

Figure 5.UCD Process Stages

(1) Understand Context of Use The system designer must understand the useful context of using such a system. Who will use the application, what they use it for and in what situations do they use the application?

(2) Specify User Requirements After the designer understands the context of the use of the application, it can proceed to the next process, namely determining user requirements. In this process, the designer must be able to determine the needs of the user in the business and the goals to be achieved.

(3) Design Solutions The next process is designing solutions from User Requirements which have been described in the previous process. This design process will go through several stages starting from rough concept, prototype to complete design. Implementation of the design based on Design solution with discussion on Understand Context of Use and Specify User Requirements. So that a prototype is made with a display on the latest website or system.

(4) Evaluation Against Requirements Evaluation will be carried out by involving the user who will use it, evaluation will be carried out starting from 1 process and proceeding to the next process. Every design that is made will inevitably have a bias because it will be influenced by human traits such as anxiety, hopes, and needs. But by using UCD, the designer can see from a more specific user point of view, what the user really needs, and to make a good design, the designer cannot use abstract things, must know concrete things. which happens in life, is applicable and feasible.

\subsection{Design Method}

In this study, a Planning Strategy was carried out using the User Centered Design (UCD) method. The concept of UCD is that the user is the center of the system development process. The objectives or properties, context and environment of the system are based on user experience. The difficulty of end users so far in reading and translating documents in each development can be helped by using the UCD method.

The Customer Relationship Management (CRM) Design Strategy will be translated step by step in the following UCD process:

(1) Understand and define the user's context. At this stage, a literature study of this method is carried out by reading and understanding reference books, journals and other media related to data processing in general that support and reinforce existing theories, so that it can instill a commitment that the design uses User 
Centered Design. (UCD) can fulfill user desires. This stage has also determined the target user. Customer data management features, from basic information to quotation and prospect data, will be handled by each member of the sales order team. Operation Supervisor access reports and monitors the performance of Sales order team members. Meanwhile, the General Sales Manager can see the overall report.

(2) Determine the needs of users and organizations. Determination of user needs is carried out by analyzing the organization by adjusting the Restaurant XYZ business process.

(3) The resulting design strategy. The statements of user requirements for the system will be collected and developed into a design solution.

Design evaluation of user needs. The design is evaluated by adjusting the needs of the user into two types of evaluation, namely formative and summative. Formative evaluation is to provide feedback that can be used to improve the design until the most suitable design is obtained. Summative evaluation is to assess whether the goals of the users and the goals of the organization are appropriate and achieved.

\subsection{Method of Collecting Data}

In this study, data collection was carried out using the following methods:

(1) Primary data of interviews with the Owner or Owner of Restaurant XYZ related to the analysis and design of the CRM system. In the form of notes on the answers to the Researcher's questions during the interview.

(2) Secondary data is obtained by studying company documents related to the CRM system. Soft copy. Where this data was provided to the author from the Director or Owner of the Restaurant XYZ. These data are collected and then analyzed and carried out compiling and making a CRM design strategy at Restaurant XYZ.

\section{Discussion and Design}

In this chapter, we will discuss the problems faced by Restaurant XYZ Restaurant which currently have not implemented Customer Relationship Management, the first stage, making an analysis of the obstacles that occur, the author uses the Fishbone Method to find out indicators of the obstacles that occur. The second stage is designing a Customer Relationship Management (CRM) Information System using the User Centered Design (UCD) method, each step by step the process of the User Centered Design (UCD) method will be accompanied by the implementation of actions.

\subsection{CRM analysis with Fishbone Method}

The fish bone method is done to help identify the root cause of a current CRM Restaurant XYZ process, as well as find ideas for solutions to problems in Restaurant XYZ. The Fishbone method has the potential to analyze problems, so that the author can understand all the problems that exist from Restaurant XYZ, as well as provide solutions for what designs should be carried out by the Restaurant XYZ owner.

The author makes the Fishbone diagram outline including the fish head which is placed on the right side of the diagram. This fish head will later be used to state the main problems faced by Restaurant XYZ. The second part is the fin, which will be used to write down the groups that cause the problem. Starting from the discussion of People; Anyone involved in the process. Methods / Management; How the process is carried out and the specific requirements for doing it, for example procedures, policies, rules and others. Machines / Equipment; Process support equipment. Materials; Raw materials, spare parts in making products. Measurement / Process; Data used to measure a process. Environment; Conditions, work culture and climate. The third part is the thorn that will be used to state the cause of the problem. From this analysis, several problems will be identified, which in the end can be identified clearly and more specifically.

The following is a discussion using the Fish Bone Diagram, this discussion is based on the results of conducting interviews with the owner or director of Restaurant XYZ. And display of indicators from groups of causes of problems that exist in Restaurant XYZ. 


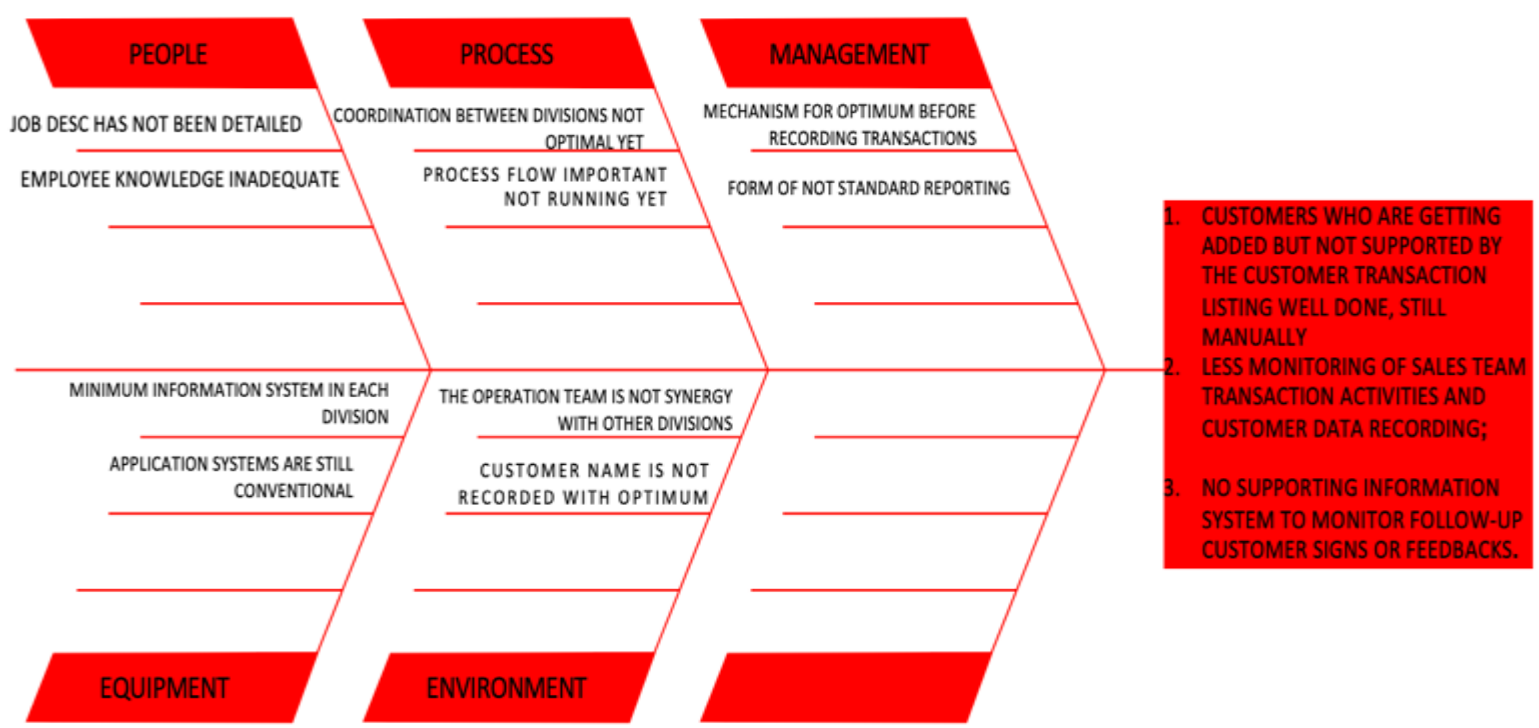

Figure 6. Fish Bone CRM Restaurant XYZ

Based on the Fishbone Diagram approach above, the authors make a solution to the constraints faced by Restaurant XYZ. Overall, the authors made a table from the Fishbone Diagram Analysis, as follows.

Table 1.Fishbone Diagram Analysis

\begin{tabular}{|c|c|c|}
\hline $\begin{array}{l}\text { Cause and Effect } \\
\text { Indicators }\end{array}$ & Obstacles & Solution \\
\hline 1. People & $\begin{array}{l}\text { 1. Job Description that is not yet detailed. } \\
\text { 2. Employee Knowledge is Inadequate. }\end{array}$ & $\begin{array}{l}\text { 1. Job Desc is made in detail and entered } \\
\text { into the system so that it is accurate in } \\
\text { determining the use of the CRM system } \\
\text { by creating Hierarchy CRM System } \\
\text { Users. } \\
\text { 2. Training for all divisions in order to } \\
\text { understand the CRM system to be } \\
\text { designed, according to Hierarchy. }\end{array}$ \\
\hline 2. Process & $\begin{array}{l}\text { 1. Coordination between divisions is not } \\
\text { optimal } \\
\text { 2. Standardization The process flow is not yet } \\
\text { running. }\end{array}$ & $\begin{array}{l}\text { 1. The design is made of a system that } \\
\text { integrates the mechanisms in each } \\
\text { workflow of a process between } \\
\text { divisions. } \\
\text { 2. The overall design of the CRM system } \\
\text { will contribute to the standardization of } \\
\text { the process flow which has not been } \\
\text { running as expected.Because the system } \\
\text { is designed to facilitate the process flow } \\
\text { between divisions. }\end{array}$ \\
\hline 3. Management & $\begin{array}{l}\text { 1. The Transaction Recording Mechanism is } \\
\text { not yet optimal. } \\
\text { 2. Forms of reporting that have not been } \\
\text { standardized. }\end{array}$ & $\begin{array}{l}\text { 1. With a CRM system design, all } \\
\text { transactions will be recorded by } \\
\text { inputting data according to the } \\
\text { transactions that occur. } \\
\text { 2. It is hoped that this transaction data } \\
\text { input will facilitate the standardization } \\
\text { of reporting as expected by the owner or } \\
\text { owner of the Restaurant XYZ. }\end{array}$ \\
\hline
\end{tabular}




\begin{tabular}{|l|l|l|l|}
\hline 4. Equipment & $\begin{array}{l}\text { Lack of information systems between } \\
\text { divisions. } \\
\text { 2. Manual application system. }\end{array}$ & $\begin{array}{l}\text { The CRM system that is designed will be } \\
\text { in the form of an information system that } \\
\text { makes it easier for employees and users } \\
\text { of the system. } \\
\text { The system design will be integrated } \\
\text { with the form of reports and transactions } \\
\text { so that there is no longer a manual } \\
\text { transaction recording process. }\end{array}$ \\
\hline 5. Environment & $\begin{array}{l}\text { The Operation Team Has Not Been } \\
\text { Synergized with Other Divisions. } \\
\text { Customer name has not been recorded } \\
\text { optimally. }\end{array}$ & $\begin{array}{l}\text { 1. } \\
\text { The design of this CRM system will } \\
\text { minimize negligence in each division } \\
\text { and create synergy in the work process } \\
\text { between divisions. } \\
\text { Designing this system will facilitate } \\
\text { transactions that occur, so that no } \\
\text { transaction records are missed. }\end{array}$ \\
&
\end{tabular}

Based on the analysis table above, the results of the Fish Bone Diagram provide important points for the Restaurant XYZ Restaurant Owner. Furthermore, to provide a solution based on the effect of the Fishbone Diagram above, the author will describe it as follows:

- To facilitate recording transactions, an integrated system is needed and makes it easier for users, this CRM system design will be a solution and provide the best contribution to Restaurant XYZ with its customers, namely by.

(1) Establish Customer Loyalty.

(2) Obtaining Customer Data.

- In addition to helping Restaurant XYZ Restaurant in designing this CRM system, in terms of improving its customers, it also functions to monitor all transactions that occur so that transaction recording becomes very measurable, one of which is.

(1) Make restaurant business activities and operations more efficient.

(2) Increase income.

- To design this CRM information system, the best method approach is needed, for that the author tries to use the Design Method with User Centered Design (UCD) as one of the options. This design is based on interviews and the wishes of the owner as the director of Restaurant XYZ.

\subsection{Problem Analysis}

From the results of the observation interview and also the analysis of the Fishbone Diagram, the writer tries to describe the problems that occur at Restaurant XYZ. In brief, the Restaurant XYZ problems are as follows:

- Increasing numbers of customers but not supported by proper recording of customer transactions, still manually.

- Lack of monitoring of the sales team's sales transaction activities and recording customer data.

- There is no supporting information system to monitor the follow-up of input or feedback from customers via the website. 


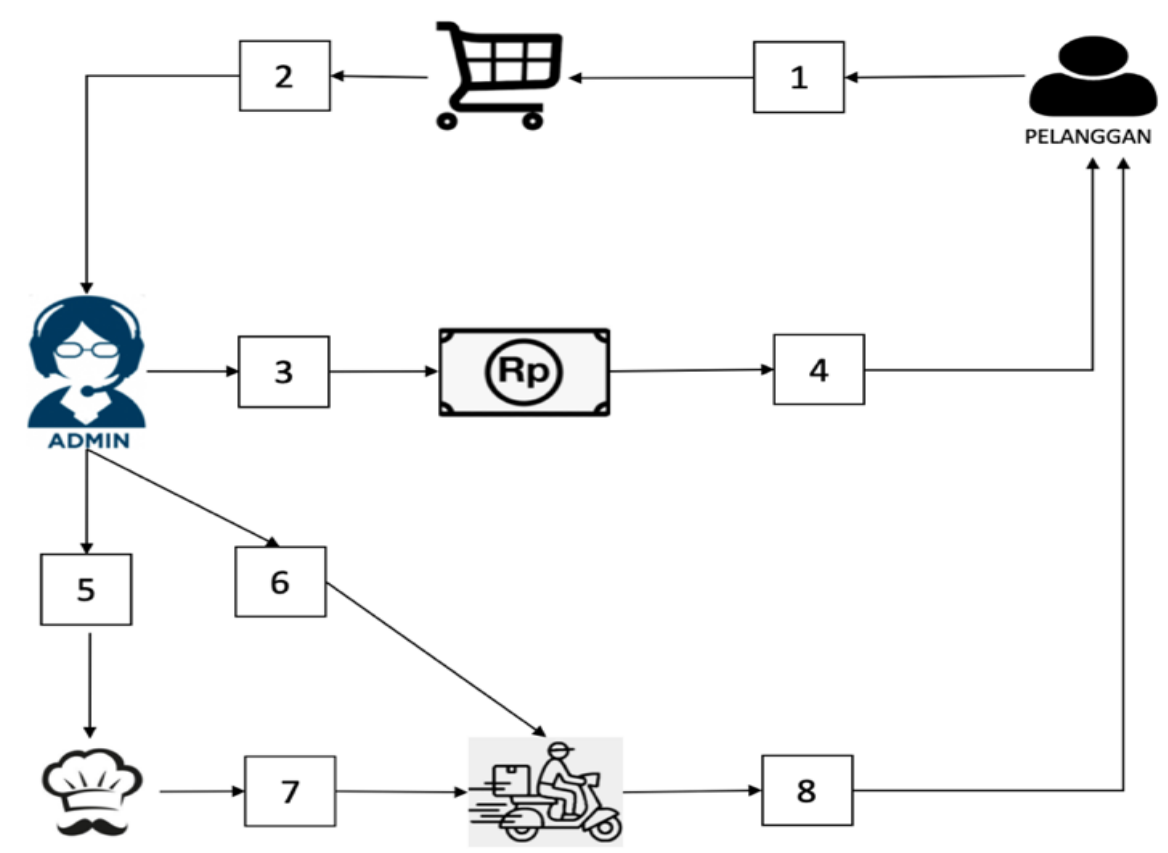

Figure 7. Flow chart of the running system

Process explanation in the image:

(1) The customer places an order by telephone / WA and tells the details of the order.

(2) Admin input the order submitted by the customer.

(3) Admin makes a note and notifies the total cost to the customer.

(4) Customers make payments via bank transfer.

(5) Admin provides order details to the Kitchen Staff.

(6) Admin gives a note to the courier for food collection.

(7) Kitchen staff delivers food to the courier and is ready for delivery.

(8) Couriers deliver food orders to customers.

\subsection{CRM System Design at Restaurant XYZ with User Centered Design (UCD) Method}

Following up on the previous discussion, this section will discuss the design of this CRM using the Use Centered Design method, where this CRM system did not exist before. Starting from recording the data of customers who order food, as well as customer habits or customer preferences in buying Restaurant XYZ products. Later it will be translated into a CRM Application System Design for Restaurant XYZ. Through this UCD Method, the author will describe and enter what is needed from each Division in Restaurant XYZ.

\subsubsection{Understand Context of Use}

Based on the problems that have been known in the previous sub-chapter, the author provides an overview of the design for the online website / application customer relationship management (CRM) by applying the User Centered Design (UCD) method to provide customer service in the culinary field. In this case the author uses internet technology. to do a case study in this thesis. The users of this CRM application are for all divisions in the Restaurant XYZ Restaurant, but each division has different authority and features, where this is adjusted based on the Hierarchy Restaurant XYZ user. 


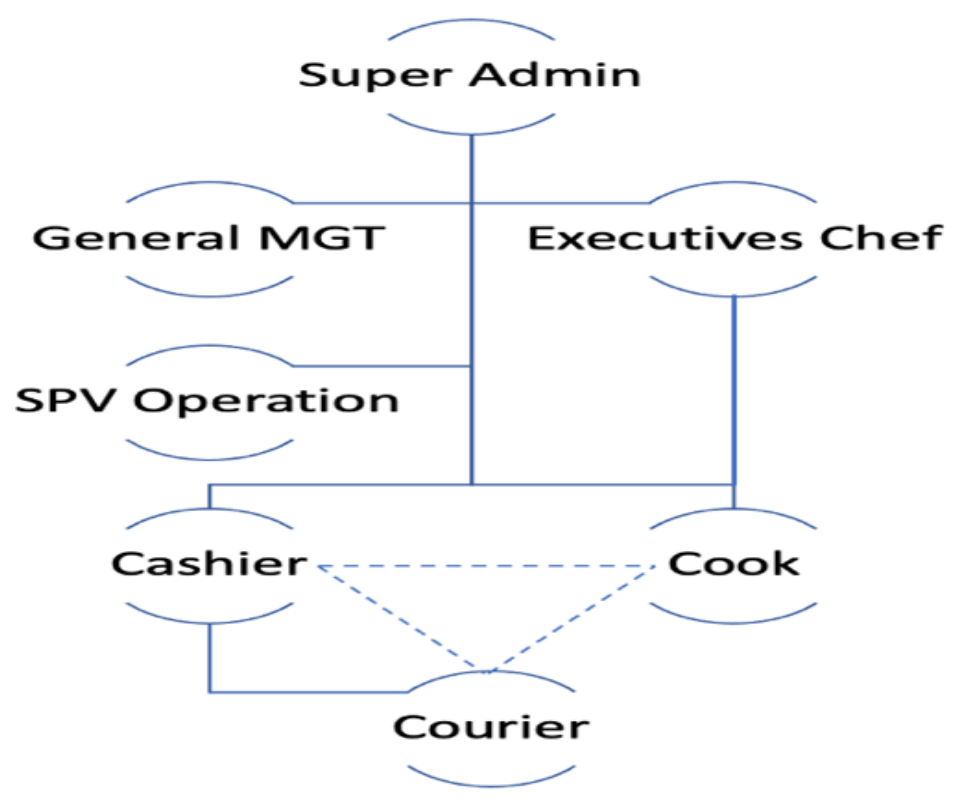

Figure 8.Restaurant XYZ User Hierarchy

\subsubsection{Specify user and Organizational Requirements}

The application system or the Customer Relationship Management (CRM) website will be designed to assist in managing and managing the Restaurant XYZ relationship with customers. Based on the results of interviews with Restaurant XYZ Owners, this CRM design aims to increase the number of new customers and provide good service for new customers and existing customers.

- Use Case Diagram

Furthermore, the design begins by making a use case diagram to be able to describe the CRM information system that will be implemented in Restaurant XYZ. Starting with the design from the side of an admin who will carry out activities to enter the CRM system.

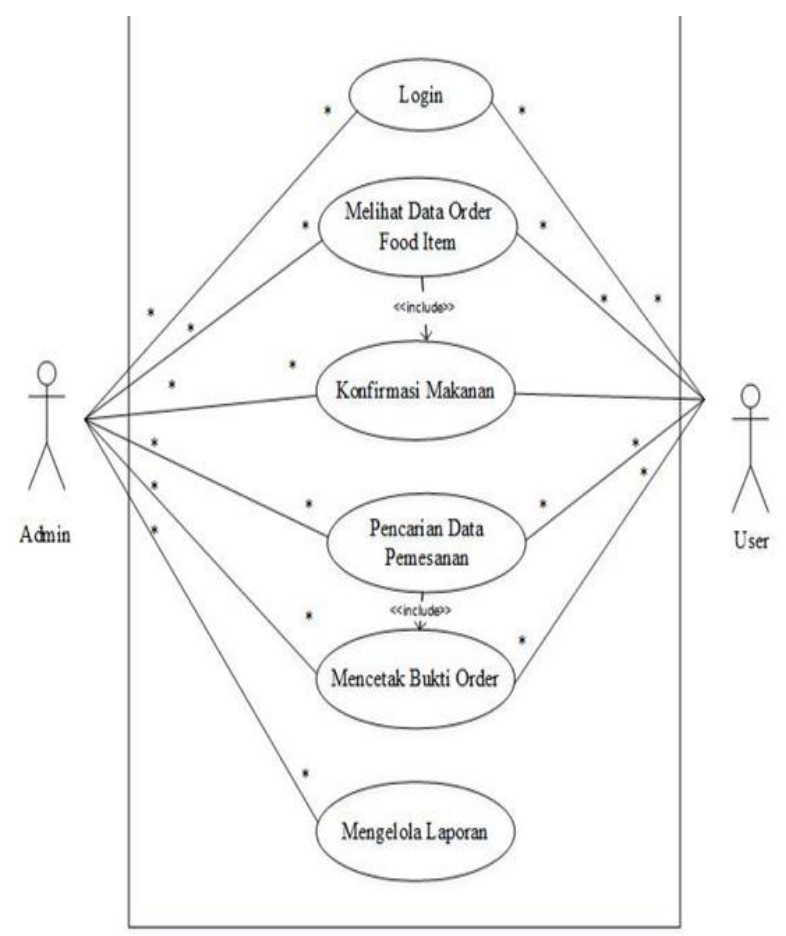

Figure 9.Use Case Diagram

- Activity Diagram 
In the next design process by making an activity diagram of each activity that runs on the website / CRM application for Restaurant XYZ. This login can be done by Super Admin, Admin, Operation, and Chef. Each user gets a different menu view after logging in.

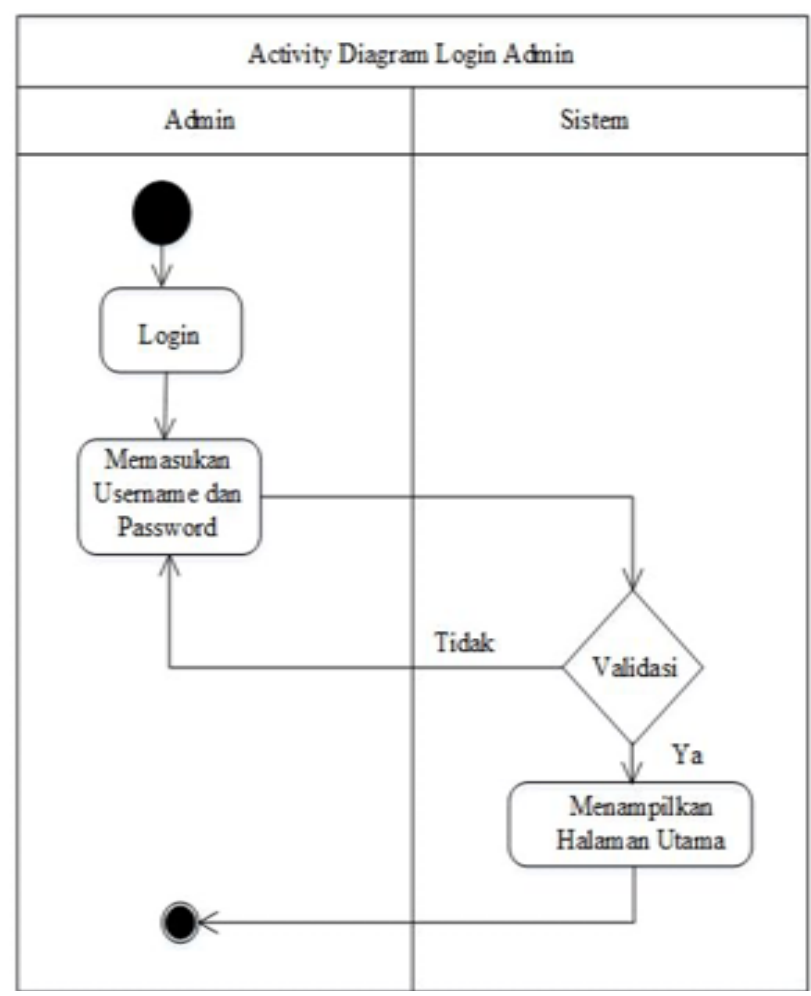

Figure 10. Admin Login

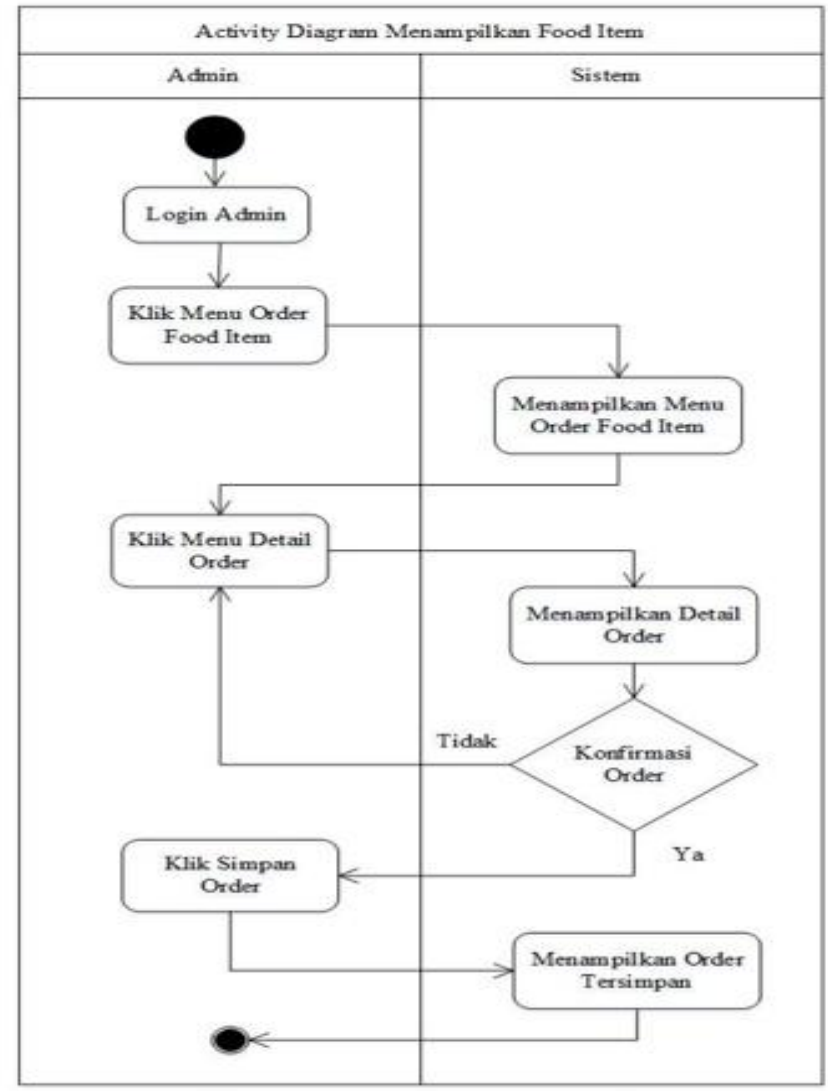

Figure 11.Showing Food Item 


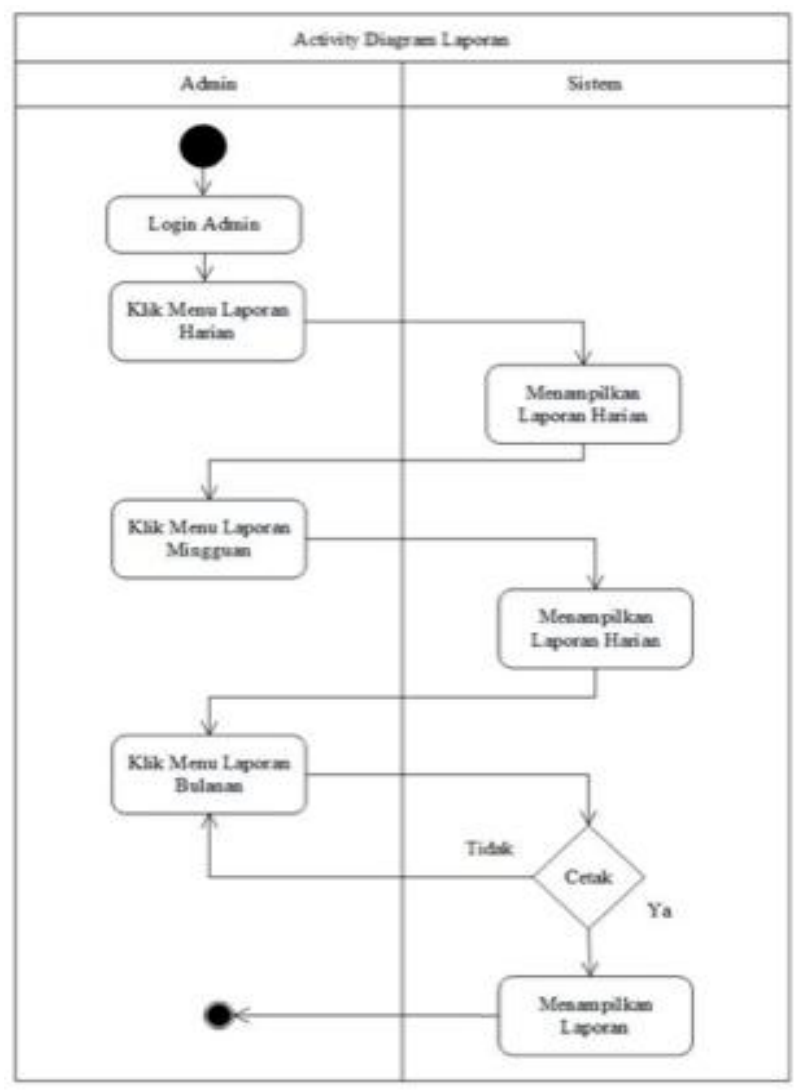

Figure 12.Reporting

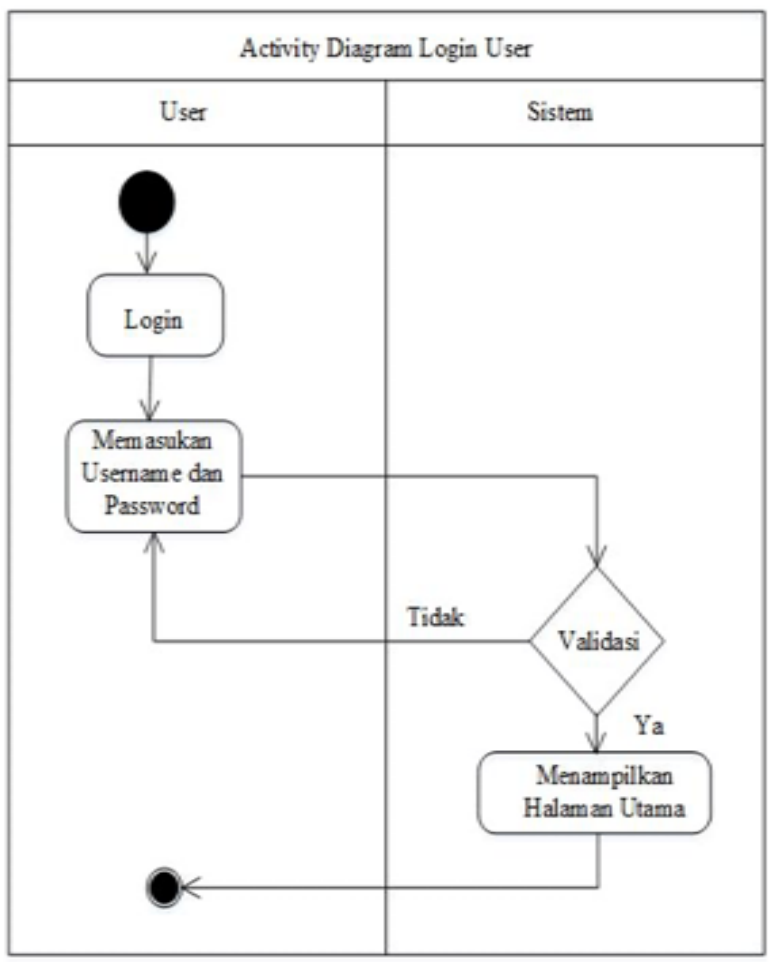

Figure 13.Login User 


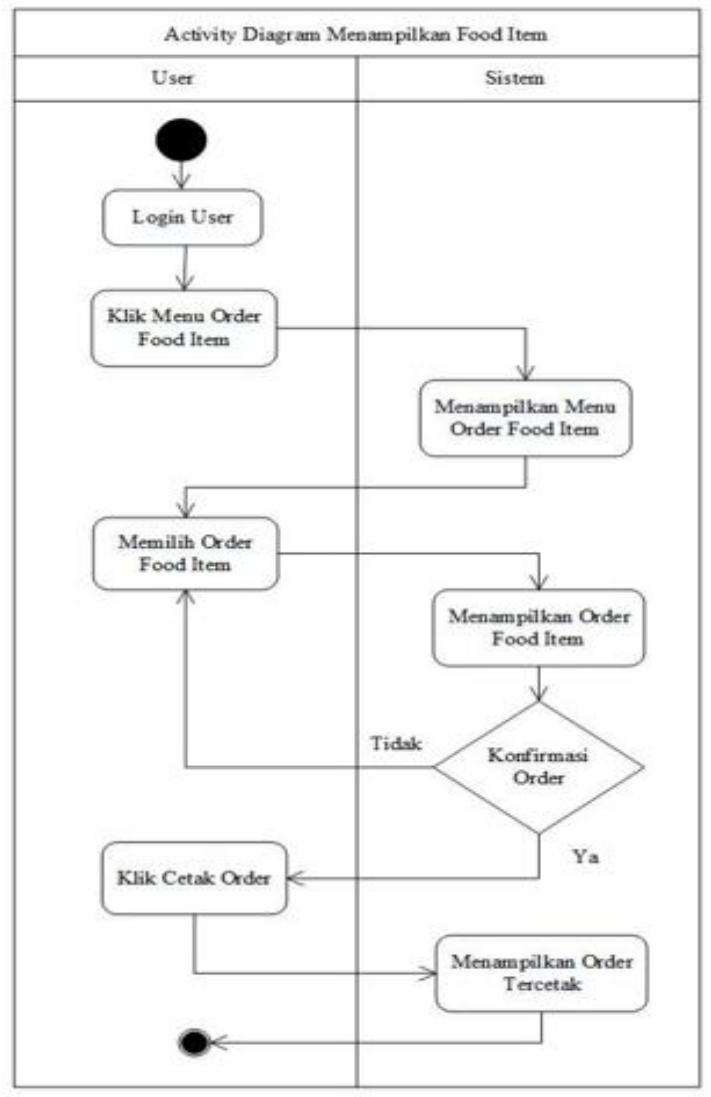

Figure 14.Food Item User.

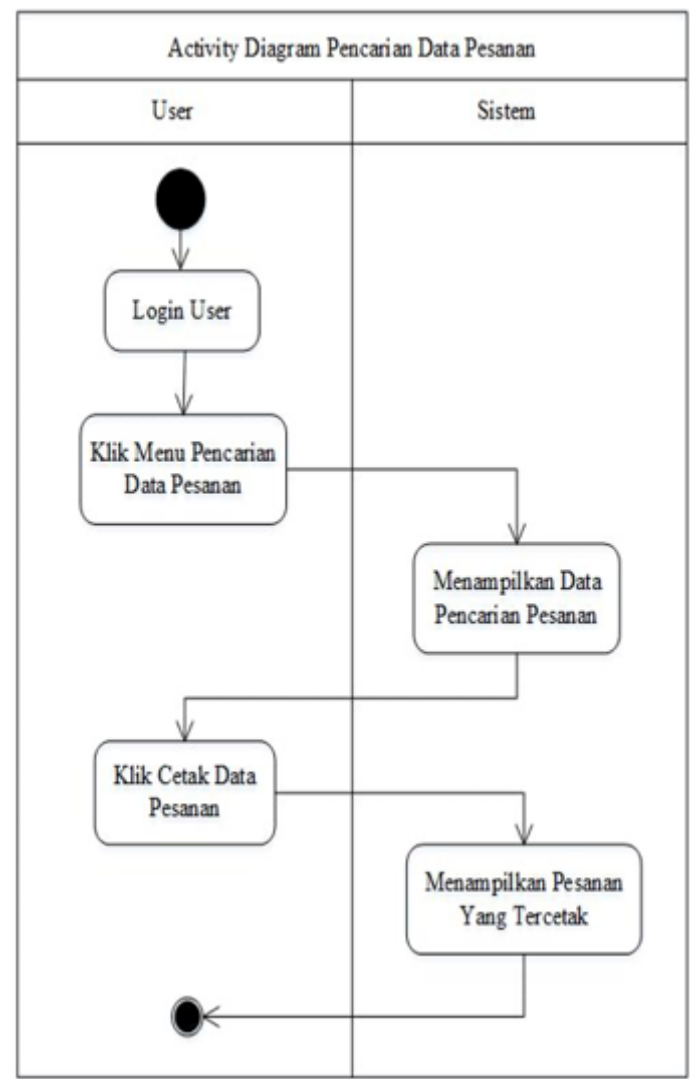

Figure 15.Data Search Order 
- Sequence Diagram

The continuation of the design of this CRM system is to create a Sequence Diagram of each process flow

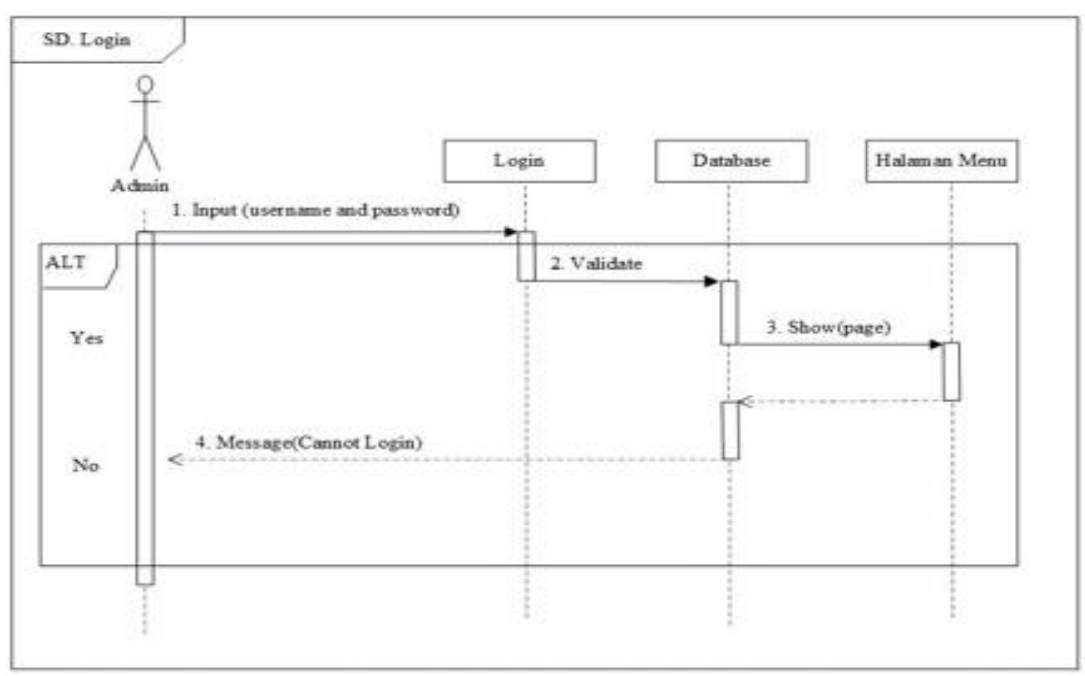

Figure 16. Login Admin

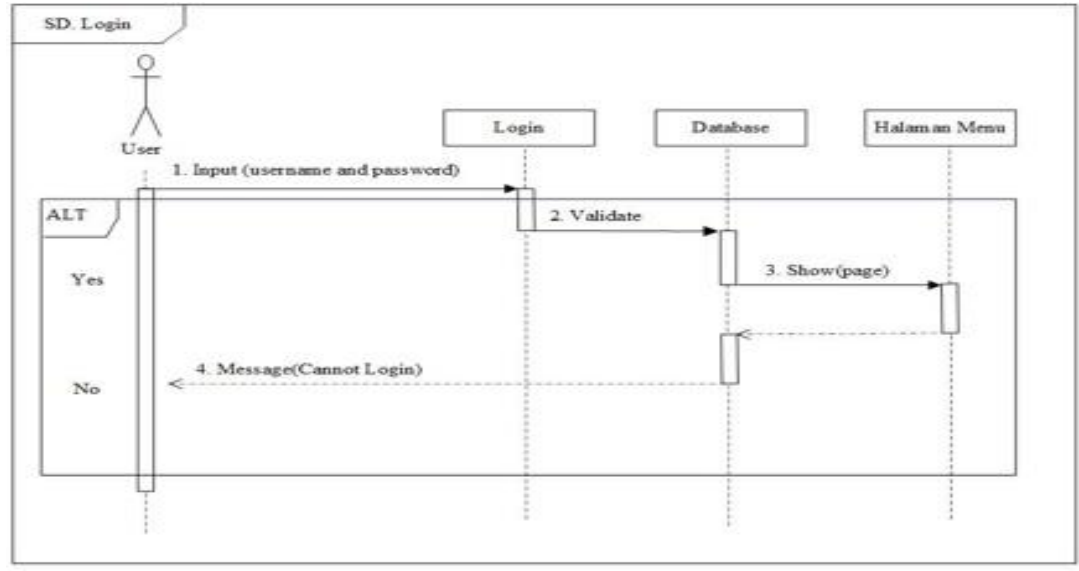

Figure 17.Login User

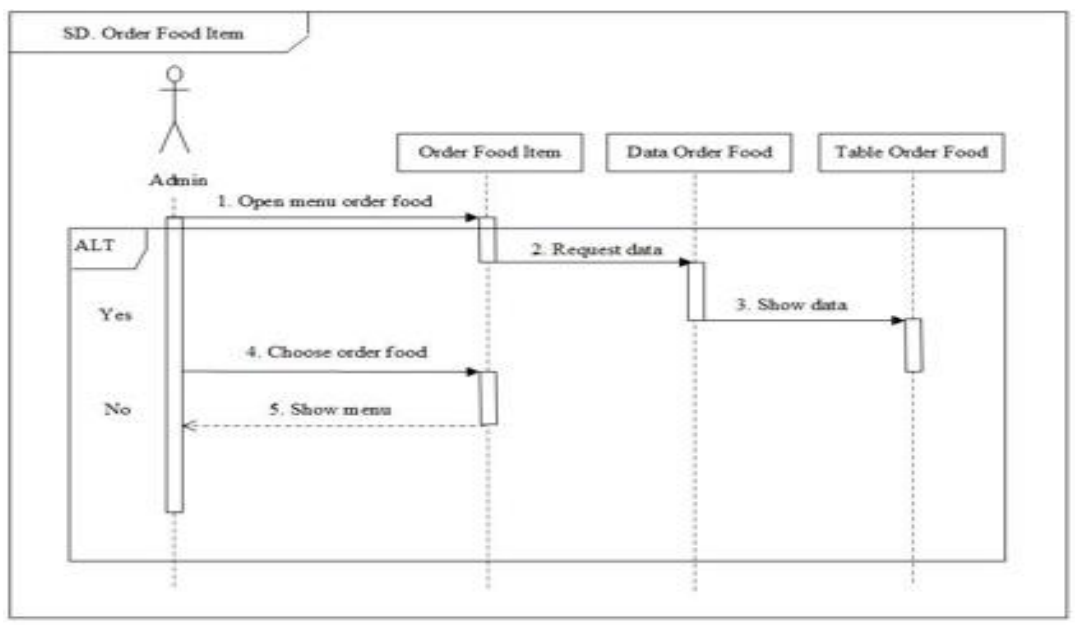

Figure 18. Data Order Food Item Admin 


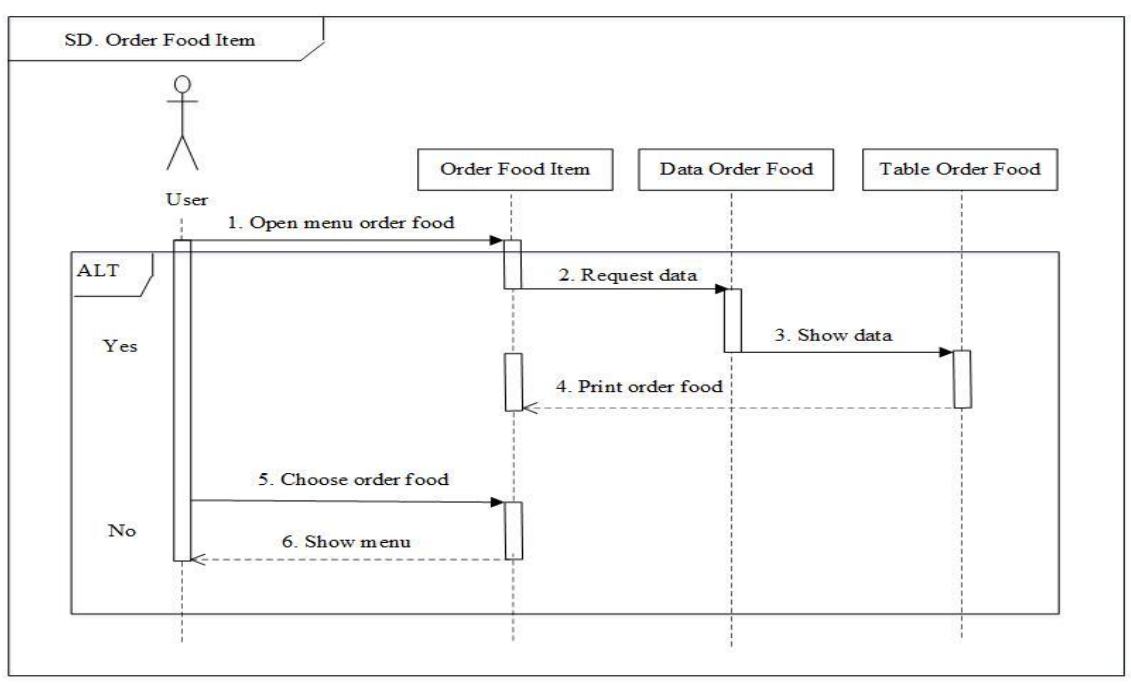

Figure 19. Data Order Food Item User

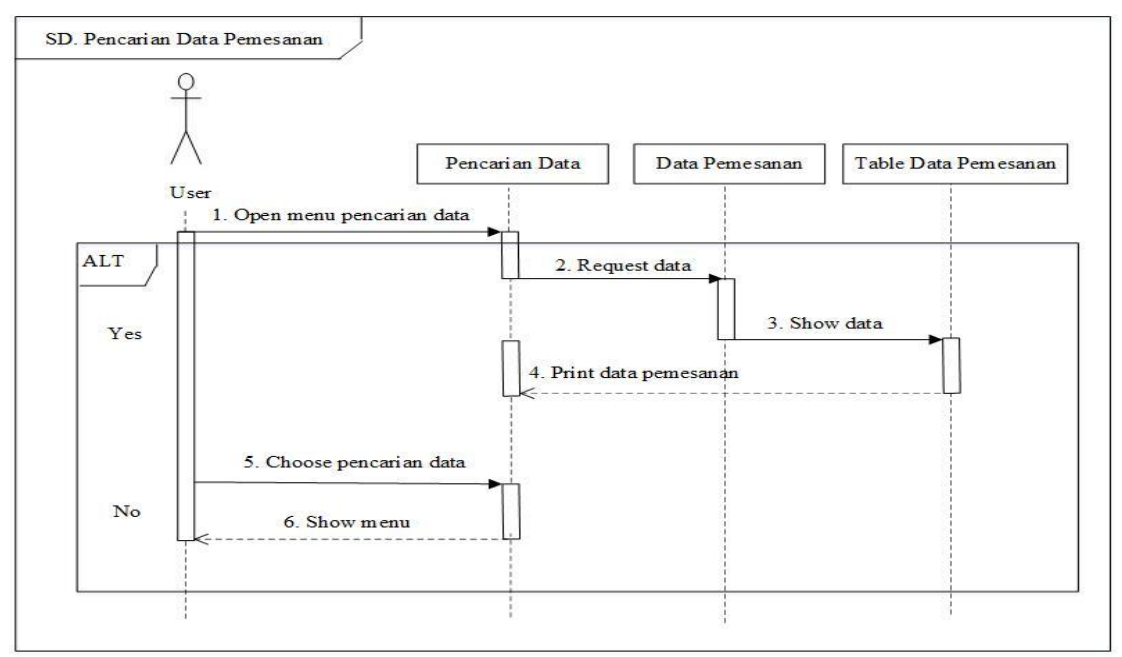

Figure 20.User Order Data Search

\section{- Class Diagram}

For this class diagram, it describes the class diagram in the user order data system that will be processed with the Restaurant XYZ. There are 5 classes with each method owned. By entering the core in the class on the system with the ordering data that handles each service. And by entering several items, namely: input system, edit, delete (delete). 


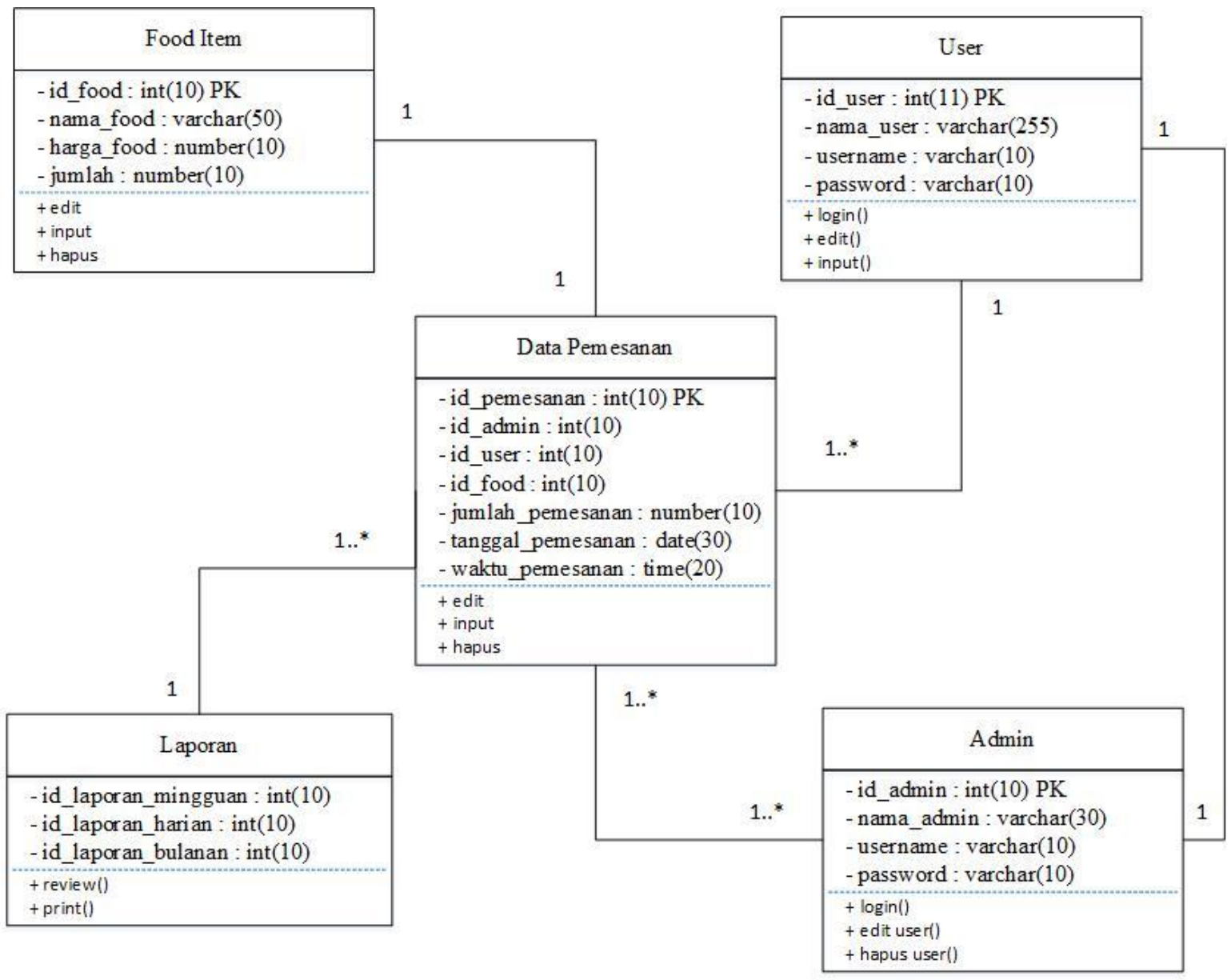

Figure 21.Class Diagram

\subsubsection{Design Solution}

In this section, the author tries to describe the solution for the CRM system which will be a reference or solution in its design. After the previous sub-chapter, which is still part of the UCD method, it has been described in determining the needs of users from Restaurant XYZ.

- Proposed CRM System Solution

The following is a system solution based on the previous description.

(1) Make it easy for customers to get the latest information about products and services.

(2) Make it easy for customers to make food product purchase transactions, both for catering and for restaurants.

(3) Make it easy for customers to convey suggestions and criticism and questions.

(4) Assist the Restaurant XYZ in managing and storing customer data and promotional schedule data.

(5) Make it easy for the Restaurant XYZ to improve the quality of service to customers, whether it is order delivery, dine in or eating at a restaurant, and for catering. 


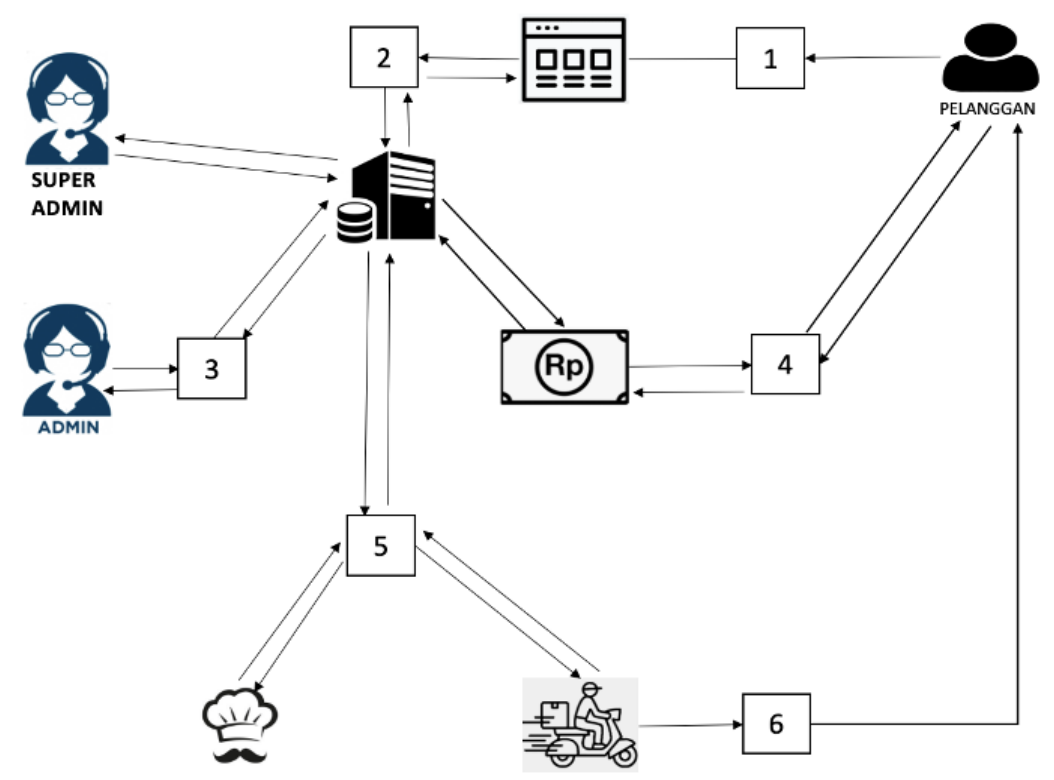

Figure 22. Flowchart of the New CRM system

The following is an explanation of the process of the image above:

(1) Customers place orders through the Website / Application and notify the details of the order, all transactions are entered into the database system, customer recording with user id, product category, menu subcategory.

(2) Admin / Super Admin reviews and follows up based on order notifications contained in the Customer database. Then the system issues a review of food item orders for the kitchen section that will be processed by the chef and cook.

(3) The system issues an order notification, including the price, notifying the total cost to the customer. Admin monitors transactions that are followed up to the kitchen after the order has been paid for with a virtual bank account.

(4) Customers make payments via bank transfer with a virtual account created by the system.

(5) The CRM system based on the data base provides order details to the Kitchen Staff to cook, after the kitchen staff gives the notification done to the system which will then be informed to the courier.

(6) The CRM system provides notifications to the Courier, both internal and external couriers for food collection and delivery to customers.

\section{- $\quad$ Prototype}

Prototype is an implementation based on CRM design or application of a system in an application program or media, which serves to become a liaison tool between the user and a computerized system. The implementation of the Restaurant XYZ Customer Relationship Management (CRM) information system is a way of implementing a system and how to run the Restaurant XYZ Customer Relationship Management (CRM) information system application program. Here the author tries to give the appearance of a new website or application, with an interface like the display below. 


\section{$\equiv$ ThmkAsta \\ Catering Makanan \\ Praktis, Murah, dan Berkualitas}

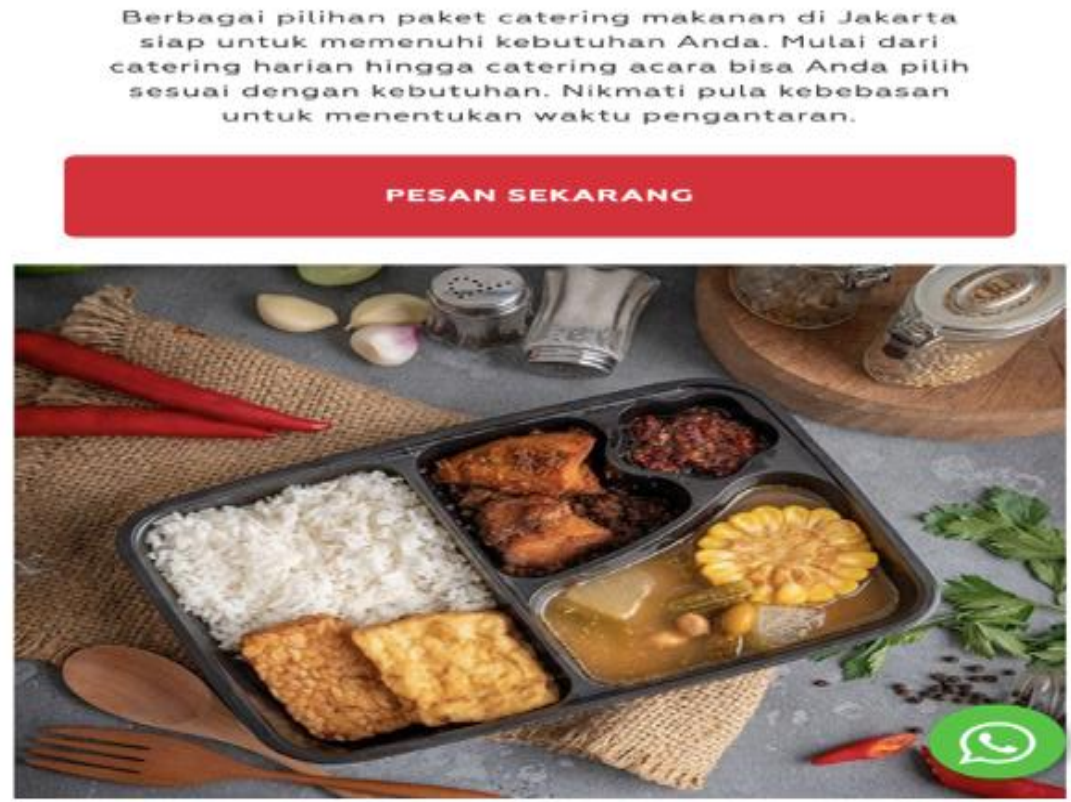

Figure 23. Website Interface

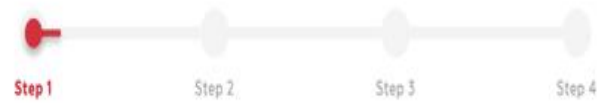

\section{Pilih Tipe Menu / Kategori}

Mohon memilih tipe menu atau kategori yang dikehendaki. Dalam 1 order Anda hanya bisa memesan menu-menu dari kategori yang sama. Untuk memesan menu dari kategori yang berbeda, mohon membuat order lainnya.
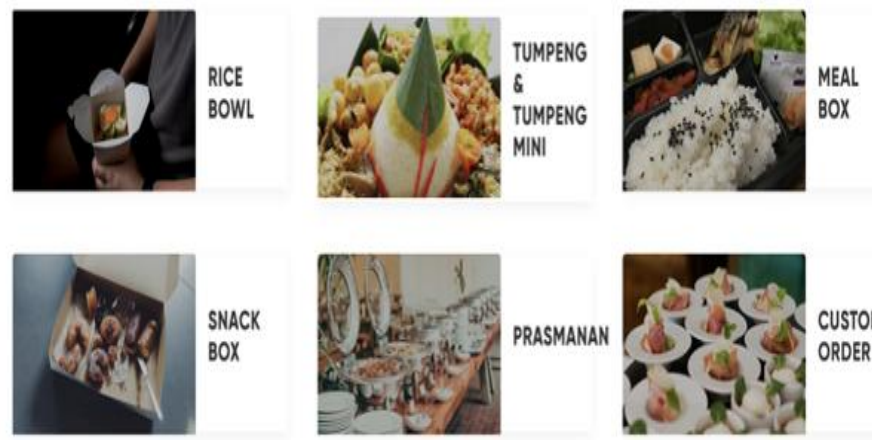

PRASMANAN

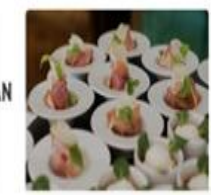

Figure 24.Menu Selection Interface 

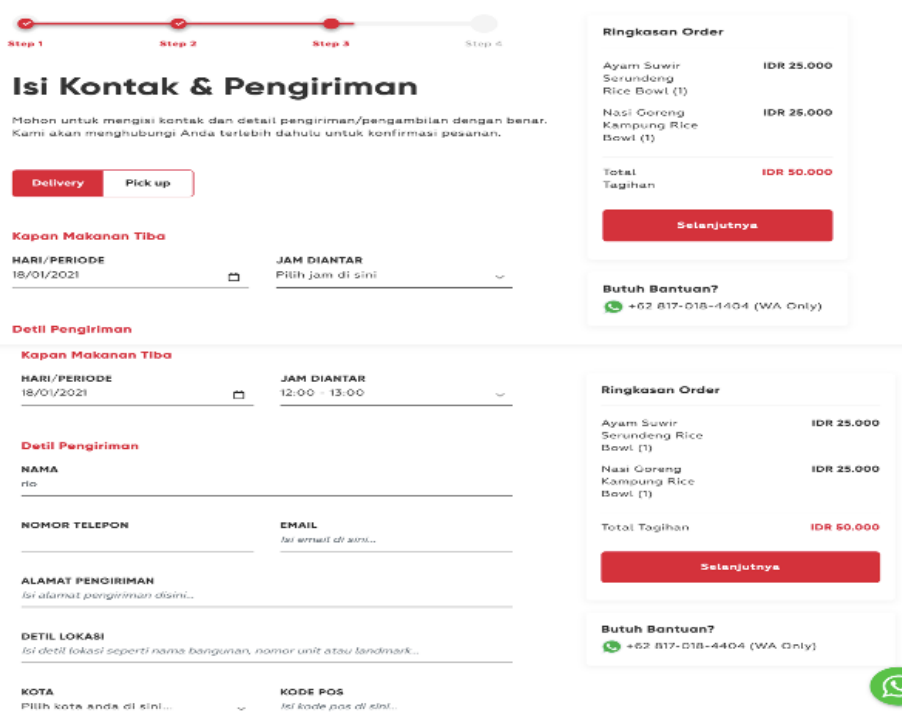

Figure 25. Customer Data Entry

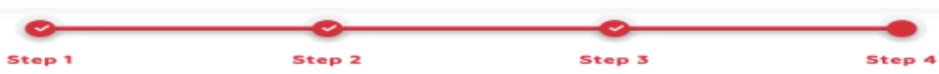

Review Order

Isi kontak dan alamet pengiriman Anda sedetil mungkin agar kami bisa

Order Pesanan Makanan Anda

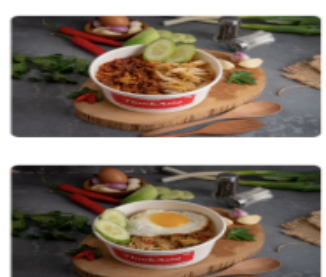

Detil Penagihan

Rio

OB1286693439 :lorio_purnomo@yahoo.com

Jl Palmerah Barat IX Gang CC No. 4 RT 006 RW 009, Palmerah Jak-

dekat dengan komolek Sandang

Jakarta Barat * 11480
Ayam Suwir Serundeng Rice Bowl

Qty: 1 Porsi

IDR 25.000

Nasi Goreng Kampung Rice Bow:

Qty: 1 Porsi

IDR 25.000

Butuh Bantuan?

C) +62 817-018-4404 (Wh Only)

Figure 26. Order Cart Interface 


\title{
Terima Kasih
}

\author{
Pesanan Anda sudah kami terima.
}

Tim kami akan segera menghubungi Anda untuk konfirmasi pesanan dan

petunjuk pembayaran. Jika membutuhkan bantuan, hubungi customer service

kami di nomor berikut

+62 817-018-4404 (WA Only)

KEMBALI KE BERANDA

Figure 27. Order completion of items

\subsubsection{Evaluate against Requirements}

The evaluation stage is the last stage in building a system. This process must provide a function that provides facilities for the feedback needed to improve a design. Another function that must be provided in this stage of the process is the facility to assess whether the objectives of the user and the organization have been achieved. There are several things that are the main concern of the evaluation results of the system, namely: very helpful for the performance of the operation team in recording new customer food item orders to handling virtual bank account payments, assisting in making reports related to customer prospects, helping the managerial team to monitor team performance operation and chef / cook, as well as the facilities provided in accordance with the objectives that have been informed in the initial chapter. The application system support is expected to provide an idea of what this design system will look like.

\subsection{Research Implications}

The design of Customer Relationship Management using the User Centered Design (UCD) method at Restaurant XYZ is very important because the functions and benefits of CRM itself, one of which is building good relationships with clients both for the short term and for the long term. The implications of CRM in Restaurant XYZ include:

\section{(1) Customers}

Forming Customer Loyalty. In terms of forming Customer Loyalty, this design makes it easy for users to get and display the latest information about menu products and services from Restaurant XYZ.

Obtaining Customer Data, making it easy for Restaurant XYZ to get accurate data based on food product purchase transactions that occur, both for catering or for restaurants. c. With this CRM design, it becomes information support in terms of monitoring input or response from customers from the menu that is served by Restaurant XYZ.

(2) Monitored transaction activities

Restaurant XYZ business activities and their operations are more efficient. Helping the Restaurant XYZ in managing and storing customer data and promotional schedule data so that business activities are more organized as well as effective and efficient. 


\section{Conclusions and Suggestions}

\subsection{Conclusion}

Based on the description and analysis that the author has described and the results of research on the data that has been collected regarding the Design of CRM (Customer Relationship Management) at Restaurant XYZ as an effort to provide customer services, then in the last stage of writing this thesis the writer draws some conclusions in accordance with the objectives of writing this thesis. After being analyzed and explained in the previous chapter, the following conclusions can be drawn:

Analysis using the Fishbone Diagram in Restaurant XYZ is very important, because using the Fishbone Diagram can contribute in terms of describing the indicators of constraints faced by Restaurant XYZ, where indicators are; People, Processes, Management, Equipment, Environment, forming or providing information about the effects that occur at Restaurant XYZ, the effects are as follows:

(1) Subscribers that are increasing but not supported by the recording of customer transactions that are done properly, still manually.

(2) Lack of monitoring of the sales team's sales transaction activities and recording customer data.

(3) There is no supporting information system to monitor follow-up input or feedback from customers.

To solve the problems faced by Restaurant XYZ in managing customer data, Restaurant XYZ uses the UCD method in designing CRM applications. The UCD method is also referred to as human-centered design. Userbased design is a term used to describe a design philosophy. The concept of UCD is that the user is the center of the system development process.

With the design of this CRM system, it will be a solution for Restaurant XYZ from an operational perspective, in this case an increase in income, as well as a solution for service to customers, in forming loyalty, obtaining customer data, as well as input or response from customers to the menu that has been enjoyed and be used as constructive input for Restaurant XYZ.

\subsection{Suggestion}

System design will continue to evolve along with adjusting various user needs for the features that have been designed. Inputs and ideas from these users are summarized in this section.

(1) The system must be accompanied by a supporting system security, using encryption to secure the information contained in the system.

(2) Can develop this Restaurant XYZ Restaurant Customer Relationship Management (CRM) Information System by using an android application.

Evaluation of the system will continue until the testing stage after the implementation of this design. So that it will produce an effective and efficient system.

\section{References}

[1] Results of a new ecraph special survey, website in access April 2020 BAPPENAS Library https://perpustakaan.bappenas.go.id

[2] Product shopping development data, website in acces April 2020; https://beritagar.id/artikel/berita/aplikasiorder-makanan-ubah-perilaku-konsumen-indonesia

[3] Lai, S. F., Hsiao, Y. C., Yang, Y. F., Huang, Y. C., \& Lee, I. C. (2009). The mediating influence of service quality satisfaction and information trust on the e-CRM process model: An empirical bank marketing research. Journal of American Academy of Business, Cambridge, 15(1), 243-253.

[4] Widhiarso, W., Jessianti, J., \&Sutini, S. (2007). Metode UCD (User Centered Design) UntukRancanganKiosInformasiStudiKasus: RumahSakitBersalin XYZ. @ lgoritma, 3(3), 6-10.

[5] Kumar, V. (2010). Customer relationship management. Wiley international encyclopedia of marketing.

[6] Kalakota, R., Robinson, M., \& Tapscott, D. (2001). E-business 2.0: Roadmap for Success (Vol. 11). Boston: Addison-Wesley.

[7] Citra Wahyu Hapsari, "Perancangan CRM (Customer Relationship Management) Pada PT. XYZ SebagaiUpayaMeningkatkanMutuPelayananPelanggan.” (2017). 
[8] Wilde, S. (2011). Customer Knowledge Management: improving customer relationship through knowledge application. Springer Science \& Business Media.

[9] Greenberg, J., Baron, R. A., \& Grover, R. A. (1993). Behavior in organizations: Understanding and managing the human side of work.

[10] Alireza, F., Ali, K., \& Aram, F. (2011). How quality, value, image, and satisfaction create loyalty at an Iran telecom. International Journal of Business and Management, 6(8), 271.

[11] Da Silva, R. V., \&Alwi, S. F. S. (2008). The link between offline brand attributes and corporate brand image in bookstores. Journal of Product \& Brand Management.

[12] Kotler, P. (2002). Hayes, Thomas, Bloom Paul N.,". Marketing Professional Service.

[13] Mowen, J. C., \& Minor, M. (1998). Consumer behavior.

[14] Dharmmesta, B. S. (1999). Loyalitaspelanggan: Sebuahkajiankonseptualsebagaipanduanbagipeneliti. Jurnalekonomi dan bisnis Indonesia, 14(3).

[15] Crosby, L. A., \& Taylor, J. R. (1983). Psychological commitment and its effects on post-decision evaluation and preference stability among voters. Journal of Consumer Research, 9(4), 413-431.

[16] Khoru Ishikawa, J.L. (1991). Introduction to quality control. Tokyo: 3A Corporation.

[17] Satzinger, J. W., Jackson, R. B., \&Burd, S. D. (2015). Systems analysis and design in a changing world. Cengage learning.

[18] Shelly, G. B., \& Rosenblatt, H. J. (2012). Systems Analysis and Design Nineth Edition. United States of America: Course Technology.

[19] Dennis, A., Wixom, B. H., \& Roth, R. M. (2012). System Analysis and Design, Fifth Edition. United States: John Wiley \& Sons, Inc.

[20] Binus SIS, access in April 2020 https://sis.binus.ac.id/2019/05/31/user-centered-design/

[21] Interaction Design Foundation, User Centered Design, access in November 2020 https://www.interactiondesign.org/literature/topics/user-centered-design 